\title{
Effect of field pea (Pisum sativum subsp. arvense (L.) Asch.) and pea-oat (Avena sativa L.) biculture cover crops on high tunnel vegetable under organic production system
}

\author{
I. Domagała-Świątkiewicz $\cdot$ P. Siwek
}

Received: 16 May 2019 / Accepted: 28 December 2021 / Published online: 1 February 2022

(C) The Author(s) 2022

\begin{abstract}
In general, adaptation of cover cropping in crop rotation practices to organic tunnels by methods supporting soil health and quality has not yet been fully optimized. Effect of field pea and pea-oat cover crops to soil physicochemical properties and cash crop quality was assessed in an organic high tunnel in southern Poland in 2016-2017, with the following planting sequence: spring cover crops/tomato/ romaine lettuce/green bean/iceberg lettuce. The sole pea produced a lower aboveground biomass (3.06 $\mathrm{t}$ $\mathrm{ha}^{-1}$ ) than the pea-oat mixture $\left(4.17 \mathrm{tha}^{-1}\right)$, and the $\mathrm{N}$ content in their biomass was $155 \mathrm{~kg} \mathrm{~N}^{-1}$ and $136 \mathrm{~kg} \mathrm{~N} \mathrm{ha}^{-1}$, respectively. The results indicated that a high residue input from cover crops was important for soil organic carbon stock, for retaining plant-available $\mathrm{N}$ in organic matter, and for improving soil physical properties, especially wet aggregate stability. We observed an increase in soil $\mathrm{pH}$ and the availability of some mineral nutrients in the soil under cover crop treatments, especially $\mathrm{Ca}, \mathrm{Mg}, \mathrm{K}$, and $\mathrm{P}$. $\mathrm{N}$ uptake
\end{abstract}

I. Domagała-Świątkiewicz $(\bowtie)$

Institute of Plant Biology and Biotechnology, Unit of Plant

Nutrition, University of Agriculture in Krakow, Al. 29

Listopada 54, 31-425 Krakow, Poland

e-mail: iwona.domagala-swiatkiewicz@urk.edu.pl; piotr.

siwek@urk.edu.pl

P. Siwek $(\bowtie)$

Department of Vegetable and Herb Plants, University of Agriculture in Krakow, Krakow, Poland e-mail: iwona.domagala-swiatkiewicz@urk.edu.pl; piotr. siwek@urk.edu.pl by the subsequent cash crop significantly ( $p \leq 0.05$ ) increased with pea than with pea-oat biculture, and in the green manure formula than with the mulch treatment. Early spring cover cropping depressed the subsequent tomato yield, but enhanced green bean yield in the second year of cropping.

Keywords Soil organic carbon - Aggregate stability · Nutrient elements · Tomato · Green bean . Lettuce

\section{Introduction}

Poland has a temperate climate and relatively short cropping seasons, so unheated high tunnels are regarded as season extension structures that allow growers to meet consumer demand for fresh, locally sourced vegetables at times which are usually offseason. Tunnel production is well suited to growing high-value crops, such as organic fruits or vegetables (O'Connell et al. 2012; Siwek and Libik 2012; Hecher et al. 2014; Janke et al. 2017). However, because of the specificity of the environment in a high plasticcovered tunnel, with no natural rainfall, limited space, and controlled growth conditions, a special set of crop management skills is required. In vegetablebased cropping systems, a lack of crop rotation within these structures leads to serious problems such as soil-borne diseases, high soil salinity, poor soil structure, decreasing microbial diversity, and consequently 
reduced crop yields (Nair et al. 2014; Rudisill et al. 2015). Among the cropping practices used for ecological intensification of production, incorporating cover crop residues and mulching the soil are common management actions in sustainable agriculture worldwide. In field experiment, the effects of rotation and cover crop (CC) residue amendment practices on vegetables have been demonstrated under conventional production system (Kołota and AdamczewskaSowińska 2013; Kaye and Quemada 2017) as well as under organic system (Campigila et al. 2012; Lawson et al. 2015), but few studies have been conducted on how these soil conservation practices influence vegetable production systems in high tunnels (Araki 2009; O'Connell et al. 2012; Rudisill et al. 2015).

One of the important determinants of vegetable productivity in high tunnels is the soil (Montri and Biernbaum 2009). A stable soil structure and high soil organic matter content encourage nutrient cycling and improve soil fertility, which finally promotes vegetable growth and increases crop quality and value (Bronic and Lal 2005; Spaccini and Piccolo 2013; Rudisill et al. 2015). Favorable effects of cover crop residue retention on the soil, especially under conservation tillage, include, among other benefits, increased soil organic matter and soil aggregation (Hartwig and Ammon 2002; McDaniel et al. 2014; Poeplau and Don 2015; Haruna and Nkongolo 2015; Kaye and Quemada 2017). Soil physical properties, such as the dynamics of waterstable macro- and microaggregates, are vital factors for maintaining the overall soil quality. The aggregation and disaggregation processes play a key role in the porosity of soil systems, which determines air, water, and nutrient availability to plants (Spaccini and Piccolo 2013). While cover crops provide many benefits, such as to build up soil organic matter, improve soil physical properties, protect from soil erosion, and suppress weed growth, their effects on the yield of the subsequent crop vary (Kumar et al 2005; Zaniewicz-Bajkowska et al. 2012; Kołota and Adamczewska-Sowińska 2013; Rudisill et al. 2015). In some cases, $\mathrm{CCs}$ increased the biomass production or yield of the subsequent crop. However, in other cases, the cover crop delivered no benefit to the subsequent crop. Cover crops can affect subsequent crop yield mainly through their influence on the use of water stored in the soil, by immobilizing $\mathrm{N}$, or, when producing excessive residues, by inhibiting crop stand establishment or harvest (Weil and Kremen 2007; Lawson et al. 2015, ZaniewiczBajkowska et al. 2012; Gieske et al. 2016). Cover crops can be used to manage nitrogen in agricultural soils by changing $\mathrm{N}$ cycling and availability. Initially, a $\mathrm{CC}$ reduces $\mathrm{N}$ availability by removing nitrate and ammonium ions from the soil. After the $\mathrm{CC}$ is terminated, this $\mathrm{N}$ becomes increasingly available as residues decompose. If the mineralization of $\mathrm{N}$ from the residue occurs too slowly, the $\mathrm{N}$ which has first been taken from the soil by the cover crop may not be available when the subsequent crop needs it. Generally, the $\mathrm{C} / \mathrm{N}$ ratio of $\mathrm{CC}$ residues influences the dynamics of organic matter mineralization (Jani et al. 2016). However, the rate of decomposition and $\mathrm{N}$ release are affected by environmental and soil characteristics (Ruffo and Bollero 2003). They reported that the decomposition of leguminous plant residue indicated that it was a potential source of available $\mathrm{N}$, while the decomposition dynamics of cereal plants showed that they were more useful in soil organic matter conservation. Establishing grass and legume $\mathrm{CC}$ species in bicultures or mixtures reduces the $\mathrm{C}$ to $\mathrm{N}$ ratio of plant residues and increases the rate of residue decomposition and $\mathrm{N}$ release (Ranells and Wagger 1997).

Diversifying crop rotations has a great potential to enhance soil ecosystem functions and is a key to maintaining soil services in agricultural systems generally. A study by McDaniel et al. (2014) showed that, over time, crop diversity influenced the processing of newly added residues, microbial dynamics, and nutrient cycling. There is a great need to examine such systems under a range of locations and growing conditions.

Therefore, the objectives of this study were (a) to demonstrate the use of cover crops in an organically managed high tunnel with the sequence of plants (2016-2017) spring cover crops/tomato/romaine lettuce/green bean/iceberg lettuce; (b) to study the effects cover crops on the physicochemical properties of the soil; and (c) to quantify their effects on the composition of the component crops and their yield under the growing conditions of southern Poland. The sequence effect of using spring cover crops (field pea monoculture or pea-oat mixture) as well as two different methods of managing the cover plant biomass (left on the soil surface as a mulch or incorporated into the soil) on soil and plant quality parameters was 
examined. The comprehensive research was related to the effects of CCs on the physicochemical properties of soil and the mineral status of cash crop plants, as well as yields and their quality.

\section{Material and methods}

\section{Experimental site}

The experiment was established in 2016 at the experimental station of the University of Agriculture in Kraków, situated in Mydlniki (N 51 ${ }^{\circ} 13^{\prime}$, E $22^{\circ} 38^{\prime}$ ) near Kraków, Poland. According to the Köppen climate classification, the area in which the station is positioned (southern Poland) belongs to the Dfb climatic region, i.e., the humid continental climate (Peel et al. 2007).

A high tunnel $($ STN $070,30 \times 7.0 \times 3.2 \mathrm{~m})$ covered with low-density polyethylene (ld PE) film 0.165 $\mathrm{mm}$ thick was constructed in an east-to-west orientation at this site in spring 2014. Previous management history at this tunnel before certification consisted of a 2-year rotation with organic cucumbers (Cucumis sativus $\mathrm{L}$.). By the use of particle size analysis (PNR-04032 1998), the soil from the location was categorized as fine-grained; its soil group was silty clay, while clay particles amounted to $40 \%$.

The microclimatic conditions in the high tunnel had been described in detail for the seasons 2014-2015 in a separate paper (Świątkiewicz et al. 2020). The microclimatic conditions (photosynthetic active radiation (PAR), air temperature, relative air humidity, air $\mathrm{CO}_{2}$ content) in the STN 070 plastic tunnel depended significantly on the weather. In the hours before and after midday, the differences were greater on a cloudy day. No significant differences were observed between the zones of the tunnel for individual parameters, especially on a sunny day.

\section{Experiment design}

In the spring season of 2016, four replications of cultivation plots were created inside of the high tunnel. All of the replicate plots had $15 \mathrm{~m}^{2}$ in size. Field pea (Pisum sativum L.) and a mixture of pea and oat (Avena sativa L.) were used as cover crops in organic high tunnel vegetable production. They were manually planted at a $10-15 \mathrm{~cm}$ distance in pea monoculture and pea-oat biculture on February 10, 2016.The early spring cover crops (CCs) were not harvested but were used as green manure (GM) incorporated into the soil, or as organic mulch (M) with the whole plants remaining on the ground as an additional organic matter input. The control plot in this experiment was bare soil covered with black plastic mulch until the start of a tomato plantation.

\section{Crop husbandry}

Tunnel operations in the vegetable production with cover crops in 2016-2017 are presented in Table 1. Prior to the start of the experiment, the soil was cultivated using a mechanical rotary cultivator.
Table 1 High tunnel operations in the vegetable production with cover crops, 2016-2017

\begin{tabular}{|c|c|c|c|}
\hline System & Year & Date & Operation \\
\hline \multirow[t]{3}{*}{ Greenhouse } & 2016 & March 16 & Sowing of tomatoes in nursery \\
\hline & & August 15 & Sowing of romaine lettuce in nursery \\
\hline & 2017 & July 4 & Sowing of iceberg lettuce in nursery modules \\
\hline \multirow[t]{8}{*}{ High tunnel } & 2016 & February 18 & Sowing of cover crop \\
\hline & & May 6 & Killing of cover crop \\
\hline & & April 29 & Transplant of tomato seedlings \\
\hline & & $\begin{array}{l}\text { July } 9 \text { to September } 12 \\
\text { September } 15\end{array}$ & $\begin{array}{l}\text { Tomato harvest } \\
\text { Soil cultivation }\end{array}$ \\
\hline & & September 16 & Transplant of romaine lettuce seedlings \\
\hline & & November 28 & Romaine lettuce harvest \\
\hline & 2017 & April 6 & Sowing of green bean \\
\hline & & $\begin{array}{l}\text { June } 14 \text { and } 16 \text { and July } 3 \\
\text { July } 26 \\
\text { September } 27\end{array}$ & $\begin{array}{l}\text { Green bean harvest } \\
\text { Transplant of iceberg lettuce seedlings } \\
\text { Iceberg lettuce harvest }\end{array}$ \\
\hline
\end{tabular}


From February (18.02.2016) to the following May (6.05.2016), the pea (Pisum sativum L.) cultivar "Milwa" and a mixture of pea and cereal oat (Avena sativa L.) were planted in two cover crop treatments without fertilization. The seeding rate in the monoculture of field pea was $250 \mathrm{~kg} \mathrm{ha}^{-1}$, and for the pea and oat biculture, the seeding density was $120 \mathrm{~kg}$ and $90 \mathrm{~kg} \mathrm{ha}^{-1}$, respectively. After cover crop termination, the plant biomass on each plot designated for $\mathrm{CC}$ was left on the soil surface of one half of the plot, and incorporated into the soil on the other half. The following substances were used during the soil fertility management: in 2014, $20 \mathrm{t}$ of cow manure was applied to the area of $1 \mathrm{ha}$; in 2017 , potash sulfate $\left(500 \mathrm{~kg} \mathrm{ha}^{-1}\right)$ was added to the cow manure prior to the sowing of green beans in order to fulfill the recommended crop nutrient requirements. All of the fertilizers were applied during the autumn season $15 \mathrm{~cm}$ deep into the soil.

Seeds of "Country Taste" F1 (HILD) tomato were sown on March 16 in greenhouse conditions. The seedlings were transplanted into the high tunnel on April 29 directly into the organic mulch of pea or peaoat, with row and plant spacing of $90 \times 80 \mathrm{~cm}$. Daily mean temperature outside the tunnel in April was $8.9^{\circ} \mathrm{C}$ and minimum $3.7^{\circ} \mathrm{C}$. The low soil temperature delayed acclimatization of the seedlings in the tunnel environment and early yielding of tomato, especially in the plots without black plastic mulch.

Yielding started on July 9 and ended on September 12 in 2016. The plots were irrigated using dripper lines. In the early period of tomato growth, in addition to standard treatments (binding and cutting), there was a need to remove weeds and oat sprouts growing out after mowing. After the tomato harvest, a vertical rotary tiller was used for soil cultivation and elimination of weedy vegetation. The romaine lettuce (Lactuca sativa var. Romana, var. Tantan) (HILD) was planted on September 16, 2016, at a spacing of $30 \times 20 \mathrm{~cm}$. Harvesting of the plants was conducted on November 28. In 2017, after mechanical elimination of weedy vegetation, seeds of the green bean (Phaseolus vulgaris L.) cultivar "Speedy" (HILD) were sown on April 6, with row and plant spacing of $50 \times 20 \mathrm{~cm}$. The plants were harvested repeatedly, on June 14 and 26, and July 3, 2017.

The last plant species in the 2-year cycle of crop rotation with cover crops in the high tunnel was the iceberg lettuce (Lactuca sativa var. capitata L.) cultivar "Vytalist" (Vitalis BZ). Seeds of the lettuce were sown on July 4, 2017, in greenhouse conditions and transplanted to the tunnel on July 26 at a spacing of $40 \times 30 \mathrm{~cm}$. The lettuce was harvested on September 27 .

Cultivation of all the species was conducted according to the principles of organic farming (certificates Pl-03-02786-16; PL-03-002786-17).

\section{Data collection}

After both the cover crop termination (which occurred on June 8, 2016) and each cash crop harvest, soil core sampler was used in order to collect soil samples from soil (0-20 cm deep). By the usage of a Kopecký's $250 \mathrm{~cm}^{3}$ cylinder, undistributed samples were gathered in four replicates from soil (0-10 $\mathrm{cm}$ deep) for the purpose of measuring bulk density. Subsequently, the process of weighing, wetting (for capillary action), and drying of soil cores at the temperature of $105^{\circ} \mathrm{C}$ occurred. From all of the plots, aggregates from undisturbed soil $(0-20 \mathrm{~cm}$ deep) were gathered in six replicates. Through the process of sieving the bulk soil, air-dried aggregates $(<5 \mathrm{~mm})$ were produced. On the top of a stacked construction of five sieves of 0.25-, 0.5-, 1.0-, 1.5-, and 2.5-mm mesh size, $40 \mathrm{~g}$ of each soil sample was placed and for $5 \mathrm{~min}$ soaked in distilled water. Afterwards, by the process of raising and lowering the sieves with a motor-driven holder, the soil samples were wet-sieved in a water container. The soil samples underwent the process of sieving for $20 \mathrm{~min}$; the frequency of sieving totaled at five $1 \mathrm{~cm}$ cycles, while $5 \mathrm{~cm}$ was the stroke length. When the wet-sieving process was completed, the soil materials from every sieve that were water-stable were oven-dried at the temperature of $105^{\circ} \mathrm{C}$ and weighed. The aggregate percentage ratio in every sieve indicates water-stable aggregates for different size classes: 5.0-2.5, 2.5-1.5, 1.5-1.0, $1.0-0.50$, and $0.50-0.25 \mathrm{~mm}$.

At a soil to water ratio of 1:2, the $\mathrm{pH}$ of soil was determined. By the use of the dichromate oxidation method, the content of soil organic carbon (SOC) was measured (Ostrowska et al. 1991). Moreover, by using the universal method, the available form of macronutrients and sodium was analyzed in 0.03 $\mathrm{mol} \mathrm{dm}{ }^{-3} \mathrm{CH}_{3} \mathrm{COOH}$. Boron (the extractable form) was determined in $1 \mathrm{~mol} \mathrm{dm}^{-3} \mathrm{HCl}$ (Ostrowska et al. 1991). The inductively coupled argon plasma 
atomic emission spectroscopy (ICP-OES) technique was used in order to determine the available forms of nutrients.

In every combination, from an area of $4 \times 1 \mathrm{~m}^{2}$, samples of the aboveground biomass were gathered before the termination of the spring cover crops. In order to estimate the total aboveground fresh biomass, plants were weighed. Green bean pods, tomato fruits, and, most importantly, mature leaves with petioles of tomato and green bean (in the half-grown vegetable stage of cash crop) were selected at random. The following procedure was applied to the gathered leaf tissue samples (cover crop and main cash crop): washing with distilled water, drying at the temperature of $65^{\circ} \mathrm{C}$ for $48 \mathrm{~h}$, and grinding for the purpose of elemental analysis. By the use of the ICP-OES technique, macroand micronutrients were determined after the process of microwave digestion in $\mathrm{HNO}_{3}$. A Prodigy High Dispersion ICP-OES Spectrometer (Teledyne Leeman Labs, Hudson NH, USA) was employed with the aim of conducting elemental analyses. The Kjeldahl method was carried out in order to determine the total nitrogen of plant material (Ostrowska et al. 1991).

The gravimetric method (PN-A-75101-03 1990) was used to measure the dry matter content of the cover crop biomass, tomato and green bean leaves and fruits, and lettuce heads. The total soluble sugars and the L-ascorbic acid content in fresh cash crop tissues were determined according to the anthrone method (Yemm and Willis 1954) and PN-A-04019 1998, respectively.

\section{Statistical analyses}

In order to compare the main effects of soil treatments (type of cover crops followed by different cover crop biomass management), statistical analysis was used. Statistica 13.1 software (Statsoft Inc.) was employed for the purpose of analyzing data. A one-way ANOVA system was used in the process of analyzing all data. Considering the combinations marked with the same letters, there is no significant difference in the mean values at the significance level of $p \leq 0.05$.

\section{Results}

Cover crop biomass and chemical composition

The spring cover crop biomass was relatively greater for the field pea-oat mixture than the field pea monoculture, but not statistically significant (Table 2). The 2016 growing season of the cover crops (February 10 to April 26) lasted for only 75 days in the high tunnel conditions. The nitrogen content in the cover crop aboveground biomass was affected by the cover crop species, and it was higher in the field pea monoculture $\left(155 \mathrm{~kg} \mathrm{~N} \mathrm{ha}^{-1}\right)$ than in the mixture with oat $(136 \mathrm{~kg}$ $\mathrm{N} \mathrm{ha}^{-1}$ ) (Table 2). In the presented study, the percentage nitrogen content in the cover crop biomass was $5.06 \%$ and $3.27 \%$, respectively, for pea and pea+oat mix (Table 3). With the exception of $\mathrm{K}, \mathrm{Na}, \mathrm{Fe}$, and $\mathrm{Mn}$, higher concentrations of nutrient elements were found in the aboveground biomass of field pea than the pea-oat mixture, especially for boron, copper, and molybdenum.

Soil analysis

In 2016, the soil bulk density (BD) found after the cover crop had been terminated was lower in the soil under the pea-oat mixture than in the control and field pea monoculture soil treatment (Table 4). After the tomato harvest in 2016, the plots mulched with cover crop residues had lower BD values than the plots where $\mathrm{CC}$ residues were incorporated into the soil, and also lower than the control plots. In the 2-year rotation, we did not observe positive effects of CC treatments on soil water capacity in the high tunnel conditions.

After the cover crop termination in 2016, the highest soil organic carbon (SOC) content was determined in

Table 2 Total fresh aboveground biomass, dry biomass ( $\mathrm{t}$ $\left.\mathrm{ha}^{-1}\right)$, dry matter (\%), and total $\mathrm{N}$ contribution $\left(\mathrm{kg} \mathrm{N} \mathrm{ha}^{-1}\right)$ of cover crops in the high tunnel

\begin{tabular}{lllll}
\hline Treatment & $\begin{array}{l}\text { Fresh bio- } \\
\text { mass }\end{array}$ & $\begin{array}{l}\text { Dry bio- } \\
\text { mass }\end{array}$ & Dry matter & $\begin{array}{l}\text { Total N } \\
\text { accumu- } \\
\text { lation }\end{array}$ \\
\hline Field pea & $24.9 \mathrm{a}$ & $3.06 \mathrm{a}$ & $12.3 \mathrm{a}$ & $155 \mathrm{~b}$ \\
Pea-oat & $30.2 \mathrm{a}$ & $4.17 \mathrm{a}$ & $13.8 \mathrm{a}$ & $136 \mathrm{a}$ \\
\hline
\end{tabular}

Means followed by the same letter in columns do not differ by Fisher test for $P \leq 0.05$ 
Table 3 Elemental composition in dry biomass of cover crops in the high tunnel

\begin{tabular}{|c|c|c|c|c|c|c|c|c|c|c|c|c|}
\hline \multicolumn{13}{|c|}{ Macronutrients and sodium (\% d.m.) } \\
\hline Treatment & $\mathrm{N}$ & $\mathrm{Ca}$ & & $\mathrm{K}$ & & $\mathrm{Mg}$ & & $\mathrm{P}$ & & $\mathrm{S}$ & & $\mathrm{Na}$ \\
\hline Field pea & $5.06 \mathrm{~b}$ & $0.48 \mathrm{a}$ & & $2.88 \mathrm{a}$ & & $0.12 \mathrm{a}$ & & $0.34 \mathrm{a}$ & & $0.23 \mathrm{a}$ & & $0.06 \mathrm{a}$ \\
\hline Pea-oat & $3.27 \mathrm{a}$ & $0.42 \mathrm{a}$ & & $3.60 \mathrm{~b}$ & & $0.11 \mathrm{a}$ & & $0.32 \mathrm{a}$ & & $0.20 \mathrm{a}$ & & $0.11 \mathrm{~b}$ \\
\hline \multicolumn{13}{|c|}{ Micronutrients (mg kg${ }^{-1}$ d.m.) } \\
\hline Treatment & $\mathrm{B}$ & & $\mathrm{Cu}$ & & $\mathrm{Fe}$ & & $\mathrm{Mn}$ & & Mo & & $\mathrm{Zn}$ & \\
\hline Field pea & $12.0 \mathrm{~b}$ & & $7.3 \mathrm{~b}$ & & $107 \mathrm{a}$ & & $17.2 \mathrm{a}$ & & $3.27 \mathrm{a}$ & & $45 \mathrm{a}$ & \\
\hline Pea-oat & $6.3 \mathrm{a}$ & & $4.9 \mathrm{a}$ & & $169 \mathrm{~b}$ & & $30.7 \mathrm{~b}$ & & $2.24 \mathrm{~b}$ & & $43 \mathrm{a}$ & \\
\hline
\end{tabular}

Means followed by the same letter in columns do not differ by Fisher test for $P \leq 0.05$

Table 4 Bulk density (g $\mathrm{cm}^{-3}$ ), soil organic carbon (SOC\%), water capacity (WC\% ww and \%wv), and water stability index (WSI\%) in soils in the high tunnel in 2016 (after cover crop termination, after tomato and romaine lettuce harvests) and 2017 (after green bean harvest)
*Field pea $M$, fresh pea biomass as mulch; field pea $G M$, pea incorporated into soil as green manure

Means followed by the same letter in columns do not differ by Fisher test for $P \leq 0.05$

\begin{tabular}{|c|c|c|c|c|c|}
\hline Treatment & $\begin{array}{l}\text { Bulk density } \\
\left(\mathrm{g} \mathrm{cm}^{-3}\right)\end{array}$ & SOC (\%) & $\mathrm{WC}(\% \mathrm{ww})$ & WC (\%wv) & WSI (\%) \\
\hline 2015 autumn & 1.34 & 1.42 & 35.4 & 47.1 & 88.8 \\
\hline \multicolumn{6}{|l|}{ Cover crop 2016} \\
\hline Control & $1.28 \mathrm{~b}$ & $1.17 \mathrm{a}$ & $35.6 \mathrm{a}$ & $43.7 \mathrm{a}$ & $87.0 \mathrm{a}$ \\
\hline Field pea & $1.31 \mathrm{~b}$ & $1.31 \mathrm{~b}$ & $35.6 \mathrm{a}$ & $45.7 \mathrm{a}$ & $93.2 \mathrm{a}$ \\
\hline Pea-oat & $1.22 \mathrm{a}$ & $1.29 \mathrm{~b}$ & $36.9 \mathrm{a}$ & $45.3 \mathrm{a}$ & $93.8 \mathrm{~b}$ \\
\hline \multicolumn{6}{|l|}{ Tomato 2016} \\
\hline Control & $1.35 \mathrm{~b}$ & $1.31 \mathrm{a}$ & $31.5 \mathrm{ab}$ & $42.4 \mathrm{a}$ & $87.7 \mathrm{a}$ \\
\hline Field pea $\mathrm{M}^{*}$ & $1.24 \mathrm{a}$ & $1.44 \mathrm{ab}$ & $33.6 \mathrm{bc}$ & $42.6 \mathrm{a}$ & $91.6 \mathrm{~b}$ \\
\hline Field pea GM & $1.37 \mathrm{~b}$ & $1.56 \mathrm{~b}$ & $31.0 \mathrm{a}$ & $43.0 \mathrm{a}$ & $91.0 \mathrm{~b}$ \\
\hline Pea-oat M & $1.25 \mathrm{a}$ & $2.14 \mathrm{~d}$ & $34.8 \mathrm{c}$ & $43.3 \mathrm{a}$ & $92.0 \mathrm{~b}$ \\
\hline Pea-oat GM & $1.28 \mathrm{a}$ & $2.34 \mathrm{e}$ & $33.9 \mathrm{bc}$ & $43.7 \mathrm{a}$ & $91.3 \mathrm{~b}$ \\
\hline \multicolumn{6}{|c|}{ Romaine lettuce 2016} \\
\hline Control & $1.33 \mathrm{~b}$ & $1.30 \mathrm{a}$ & $34.5 \mathrm{a}$ & $45.1 \mathrm{a}$ & $92.7 \mathrm{a}$ \\
\hline Field pea & $1.27 \mathrm{a}$ & $1.31 \mathrm{a}$ & $35.0 \mathrm{a}$ & $44.8 \mathrm{a}$ & $92.5 \mathrm{a}$ \\
\hline Pea-oat & $1.28 \mathrm{a}$ & $1.99 \mathrm{~b}$ & $40.7 \mathrm{~b}$ & $46.0 \mathrm{a}$ & $94.9 \mathrm{~b}$ \\
\hline \multicolumn{6}{|l|}{ Green bean 2017} \\
\hline Control & $1.37 \mathrm{~b}$ & $1.44 \mathrm{a}$ & $31.5 \mathrm{a}$ & $42.4 \mathrm{a}$ & $92.3 \mathrm{a}$ \\
\hline Field pea & $1.25 \mathrm{a}$ & $1.49 \mathrm{a}$ & $33.6 \mathrm{~b}$ & $42.6 \mathrm{a}$ & $96.2 \mathrm{c}$ \\
\hline Pea-oat & $1.36 \mathrm{~b}$ & $1.60 \mathrm{~b}$ & $31.0 \mathrm{a}$ & $43.0 \mathrm{a}$ & $94.6 \mathrm{~b}$ \\
\hline \multicolumn{6}{|c|}{ Iceberg lettuce 2017} \\
\hline Control & $1.29 \mathrm{~b}$ & $1.27 \mathrm{a}$ & $33.4 \mathrm{a}$ & $42.8 \mathrm{a}$ & $93.0 \mathrm{a}$ \\
\hline Field pea & $1.23 \mathrm{ab}$ & $1.50 \mathrm{c}$ & $35.4 \mathrm{a}$ & $44.2 \mathrm{a}$ & $92.5 \mathrm{a}$ \\
\hline Pea-oat & $1.20 \mathrm{a}$ & $1.42 \mathrm{~b}$ & $35.9 \mathrm{a}$ & $44.1 \mathrm{a}$ & $95.0 \mathrm{~b}$ \\
\hline
\end{tabular}

the soils under the cover crop treatment (Table 4). This trend was also found in the soils after the tomato harvest in 2016, especially for the plots where CC residues were incorporated into the soil. The highest SOC values were recorded for the soils treated with the pea-oat mixture. This significant effect was also evident after the romaine lettuce harvest in 2016 and in the second year of the experiment after green bean and iceberg lettuce cultivation in 2017. In autumn 2016, the soil under the monoculture pea treatment already contained an SOC amount comparable with that of the control soil.

In both years of the high tunnel experiment, the highest water-stable aggregate index (WSI), expressed as the sum of the $0.25-5.0 \mathrm{~mm}$ water-stable aggregate fractions, was found in the soils under the field peaoat mixture treatment (Table 5). The distribution of 
water-stable aggregates characterizing the initial soil samples, before the start of the high tunnel experiment (autumn 2015), showed a significant effect of textural composition on soil structural properties. An increase in the stability of macroaggregates and a decrease in the amount of microaggregates were found after the cover crops had been terminated in 2016, in comparison with the initial soil and the control soil (Table 5). Macroaggregates $(2.5-5.0 \mathrm{~mm})$ constituted $18.5-28.3 \%$ of water-stable aggregates and varied significantly among the treatments. After the tomato harvest in 2016, the trend to increase the macroaggregate content in the soil under the field pea treatment was observed irrespective of plant residue management. This effect was also observed after the green bean harvest in 2017. The water-resistant soil structure under the pea-oat treatment was characterized by a higher number of aggregates $1.0-0.50 \mathrm{~mm}$ in diameter, especially in the first year of our experiment (Table 5).

The nutrient element content in the control soils (bare soil under black polypropylene mulch during CC plantation) or soils under $\mathrm{CC}$ treatments was determined after the cover crops had been terminated (Table 6). The concentrations of potassium, magnesium, and phosphorus (only in pea-oat plots) were higher in the CC-treated soil than in the plastic-mulched soil (control).

Soil analysis data obtained after the tomato harvest in September 2016 indicated that the plots under $\mathrm{CC}$ treatments had significantly higher $\mathrm{pH}$ values $(\mathrm{pH}$ 7.17-7.43) compared to the control soil ( $\mathrm{pH}$ 6.94) (Table 6). The tendency to decrease the concentration of soluble salts in the soil solution was also evident. The concentrations of $\mathrm{NH}_{4}{ }^{+}$were very low and those of $\mathrm{NO}_{3}{ }^{-}$showed no statistically significant differences in the soils treated with $\mathrm{CC}$ residues. However, a tendency towards slightly elevated $\mathrm{NO}_{3}{ }^{-}$concentrations was detected in the soil under treatment with $\mathrm{CCs}$ as green manure formula (GM). The concentration of $\mathrm{Ca}$ and $\mathrm{Mg}$ in the soils was from low (the control and pea $\mathrm{M}$ ) to high according to the guide values estimated using the universal method (Sady 2000). A high concentration of these nutrients was found in the
Table 5 Percentages for five classes of soil waterstable aggregates $(\mathrm{mm})$ in soils in the high tunnel (before and after cover crop termination)

See Table 4 for explanation

\begin{tabular}{|c|c|c|c|c|c|}
\hline \multirow[t]{2}{*}{ Treatment } & \multicolumn{5}{|c|}{ Percentage of water-stable aggregates with diameter (mm) } \\
\hline & $5.0-2.5$ & $2.5-1.5$ & $1.5-1.0$ & $1.0-0.50$ & $0.50-0.25$ \\
\hline Autumn 2015 & $16.2 \pm 1.1$ & $13.2 \pm 2.3$ & $14.5 \pm 1.3$ & $24.3 \pm 1.6$ & $20.6 \pm 3.7$ \\
\hline \multicolumn{6}{|l|}{ Cover crop 2016} \\
\hline Control & $18.5 \mathrm{a}$ & $13.1 \mathrm{a}$ & $13.2 \mathrm{a}$ & $24.0 \mathrm{~b}$ & $19.7 \mathrm{~b}$ \\
\hline Field pea & $28.3 \mathrm{c}$ & $19.6 \mathrm{~b}$ & $15.0 \mathrm{~b}$ & $18.4 \mathrm{a}$ & $12.0 \mathrm{a}$ \\
\hline Pea-oat & $23.7 \mathrm{~b}$ & $17.5 \mathrm{~b}$ & $16.4 \mathrm{~b}$ & $23.3 \mathrm{~b}$ & $13.2 \mathrm{a}$ \\
\hline \multicolumn{6}{|l|}{ Tomato 2016} \\
\hline Control & $30.9 \mathrm{~b}$ & $19.0 \mathrm{~b}$ & $13.0 \mathrm{a}$ & $17.9 \mathrm{ab}$ & $8.0 \mathrm{a}$ \\
\hline Field pea M & $32.5 \mathrm{~b}$ & $21.4 \mathrm{c}$ & $13.2 \mathrm{a}$ & $17.0 \mathrm{a}$ & $8.2 \mathrm{a}$ \\
\hline Field pea GM & $32.4 \mathrm{~b}$ & $16.5 \mathrm{a}$ & $13.0 \mathrm{a}$ & $20.1 \mathrm{bc}$ & $10.0 \mathrm{~b}$ \\
\hline Pea-oat M & $26.0 \mathrm{a}$ & $19.0 \mathrm{~b}$ & $15.7 \mathrm{a}$ & $21.8 \mathrm{~cd}$ & $10.5 \mathrm{~b}$ \\
\hline Pea-oat GM & $25.5 \mathrm{a}$ & $17.2 \mathrm{ab}$ & $15.4 \mathrm{a}$ & $24.8 \mathrm{~d}$ & $9.3 \mathrm{ab}$ \\
\hline \multicolumn{6}{|c|}{ Romaine lettuce 2016} \\
\hline Control & $32.1 \mathrm{a}$ & $20.2 \mathrm{a}$ & $15.4 \mathrm{a}$ & $17.9 \mathrm{~b}$ & $7.4 \mathrm{a}$ \\
\hline Field pea & $38.1 \mathrm{~b}$ & $19.1 \mathrm{a}$ & $13.6 \mathrm{a}$ & $14.7 \mathrm{a}$ & $7.0 \mathrm{a}$ \\
\hline Pea-oat & $32.0 \mathrm{a}$ & $19.2 \mathrm{a}$ & $13.9 \mathrm{a}$ & $19.6 \mathrm{~b}$ & $10.2 \mathrm{~b}$ \\
\hline \multicolumn{6}{|l|}{ Green bean 2017} \\
\hline Control & $27.9 \mathrm{a}$ & $15.0 \mathrm{a}$ & $13.3 \mathrm{a}$ & $24.8 \mathrm{~b}$ & $11.6 \mathrm{a}$ \\
\hline Field pea & $34.2 \mathrm{~b}$ & $18.4 \mathrm{~b}$ & $15.8 \mathrm{ab}$ & $17.2 \mathrm{a}$ & $10.7 \mathrm{a}$ \\
\hline Pea-oat & $26.1 \mathrm{a}$ & $16.0 \mathrm{a}$ & $17.5 \mathrm{~b}$ & $23.0 \mathrm{~b}$ & $12.0 \mathrm{a}$ \\
\hline \multicolumn{6}{|c|}{ Iceberg lettuce 2017} \\
\hline Control & $35.3 \mathrm{a}$ & $19.9 \mathrm{~b}$ & $13.3 \mathrm{a}$ & $15.5 \mathrm{a}$ & $8.9 \mathrm{a}$ \\
\hline Field pea & $38.4 \mathrm{~b}$ & $16.5 \mathrm{a}$ & $12.4 \mathrm{a}$ & $15.2 \mathrm{a}$ & $10.0 \mathrm{a}$ \\
\hline Pea-oat & $38.5 \mathrm{~b}$ & $17.8 \mathrm{a}$ & $14.9 \mathrm{~b}$ & $15.5 \mathrm{a}$ & $8.3 \mathrm{a}$ \\
\hline
\end{tabular}


Table 6 Soil acidity $(\mathrm{pH})$, electrical conductivity (EC $\mathrm{mS} \mathrm{cm}^{-1}$ ), and macroelement concentration ( $\mathrm{mg} \mathrm{dm}^{-3}$ of fresh soil) in soils in the high tunnel after cover crop termination in 2016 and after cash crop harvest
See Table 4 for explanation, *after potassium sulfate fertilization

\begin{tabular}{lccccccccc}
\hline Treatment & $\mathrm{pH}$ & $\mathrm{EC}$ & $\mathrm{N}^{-N H_{4}}$ & $\mathrm{~N}^{-N O_{3}}$ & $\mathrm{Ca}$ & $\mathrm{K}$ & $\mathrm{Mg}$ & $\mathrm{P}$ & $\mathrm{S}$ \\
\hline Autumn 2015 & 7.32 & 0.32 & - & - & 1667 & 64 & 70 & 25 & 36 \\
Cover crop 2016 & & & & & & & & & \\
Control & $7.20 \mathrm{a}$ & $0.27 \mathrm{a}$ & $0.54 \mathrm{a}$ & $8.03 \mathrm{~b}$ & $1618 \mathrm{a}$ & $53 \mathrm{a}$ & $144 \mathrm{a}$ & $40 \mathrm{a}$ & $56 \mathrm{a}$ \\
Field pea & $7.28 \mathrm{ab}$ & $0.12 \mathrm{a}$ & $0.81 \mathrm{a}$ & $1.18 \mathrm{a}$ & $2151 \mathrm{a}$ & $92 \mathrm{~b}$ & $173 \mathrm{~b}$ & $38 \mathrm{a}$ & $67 \mathrm{a}$ \\
Pea-oat & $7.37 \mathrm{~b}$ & $0.17 \mathrm{a}$ & $0.84 \mathrm{a}$ & $0.23 \mathrm{a}$ & $1793 \mathrm{a}$ & $116 \mathrm{c}$ & $169 \mathrm{~b}$ & $48 \mathrm{~b}$ & $77 \mathrm{a}$ \\
Tomato 2016 & & & & & & & & & \\
Control & $6.94 \mathrm{a}$ & $0.30 \mathrm{a}$ & Trace & $19.5 \mathrm{a}$ & $778 \mathrm{a}$ & $40 \mathrm{a}$ & $102 \mathrm{a}$ & $23 \mathrm{ab}$ & $59 \mathrm{a}$ \\
Field pea M & $7.17 \mathrm{ab}$ & $0.22 \mathrm{a}$ & Trace & $18.7 \mathrm{a}$ & $655 \mathrm{a}$ & $50 \mathrm{a}$ & $87 \mathrm{a}$ & $16 \mathrm{a}$ & $62 \mathrm{a}$ \\
Field pea GM & $7.21 \mathrm{bc}$ & $0.20 \mathrm{a}$ & Trace & $25.5 \mathrm{a}$ & $1958 \mathrm{~d}$ & $88 \mathrm{c}$ & $137 \mathrm{~b}$ & $26 \mathrm{bc}$ & $57 \mathrm{a}$ \\
Pea-oat M & $7.43 \mathrm{c}$ & $0.14 \mathrm{a}$ & Trace & $23.7 \mathrm{a}$ & $1102 \mathrm{~b}$ & $66 \mathrm{~b}$ & $136 \mathrm{~b}$ & $34 \mathrm{~cd}$ & $39 \mathrm{a}$ \\
Pea-oat GM & $7.33 \mathrm{bc}$ & $0.22 \mathrm{a}$ & Trace & $32.5 \mathrm{a}$ & $1420 \mathrm{c}$ & $42 \mathrm{a}$ & $153 \mathrm{~b}$ & $44 \mathrm{~d}$ & $40 \mathrm{a}$ \\
Romaine lettuce 2016 & & & & & & & & \\
Control & $7.26 \mathrm{a}$ & $0.20 \mathrm{a}$ & $0.37 \mathrm{a}$ & $21.0 \mathrm{a}$ & $1184 \mathrm{a}$ & $21 \mathrm{a}$ & $167 \mathrm{a}$ & $40 \mathrm{a}$ & $49 \mathrm{a}$ \\
Field pea & $7.20 \mathrm{a}$ & $0.20 \mathrm{a}$ & $2.18 \mathrm{~b}$ & $41.0 \mathrm{~b}$ & $1640 \mathrm{~b}$ & $110 \mathrm{~b}$ & $201 \mathrm{a}$ & $56 \mathrm{a}$ & $77 \mathrm{~b}$ \\
Pea-oat & $7.40 \mathrm{a}$ & $0.26 \mathrm{a}$ & $0.00 \mathrm{a}$ & $21.0 \mathrm{a}$ & $1229 \mathrm{a}$ & $92 \mathrm{~b}$ & $141 \mathrm{a}$ & $45 \mathrm{a}$ & $78 \mathrm{~b}$ \\
Green bean 2017 & & & & & & & & & \\
Control & $7.48 \mathrm{a}$ & $0.72 \mathrm{a}$ & $6.63 \mathrm{a}$ & $66.9 \mathrm{~b}$ & $1843 \mathrm{a}$ & $218 * \mathrm{a}$ & $196 \mathrm{a}$ & $47 \mathrm{a}$ & $211^{*} \mathrm{ab}$ \\
Field pea & $7.60 \mathrm{a}$ & $0.47 \mathrm{a}$ & $8.47 \mathrm{a}$ & $37.1 \mathrm{a}$ & $1916 \mathrm{a}$ & $246 \mathrm{a}$ & $207 \mathrm{a}$ & $49 \mathrm{a}$ & $167 \mathrm{a}$ \\
Pea-oat & $7.49 \mathrm{a}$ & $0.62 \mathrm{a}$ & $6.71 \mathrm{a}$ & $82.0 \mathrm{~b}$ & $2477 \mathrm{~b}$ & $288 \mathrm{a}$ & $274 \mathrm{~b}$ & $67 \mathrm{~b}$ & $269 \mathrm{~b}$ \\
Iceberg lettuce 2017 & & & & & & & & & \\
Control & $7.71 \mathrm{a}$ & $0.09 \mathrm{a}$ & $6.78 \mathrm{a}$ & $2.73 \mathrm{a}$ & $1614 \mathrm{a}$ & $85 \mathrm{a}$ & $129 \mathrm{a}$ & $37 \mathrm{a}$ & $35 \mathrm{c}$ \\
Field pea & $7.97 \mathrm{a}$ & $0.11 \mathrm{a}$ & $9.30 \mathrm{a}$ & $2.52 \mathrm{a}$ & $1804 \mathrm{a}$ & $149 \mathrm{~b}$ & $140 \mathrm{a}$ & $49 \mathrm{a}$ & $27 \mathrm{~b}$ \\
Pea-oat & $7.89 \mathrm{a}$ & $0.10 \mathrm{a}$ & $8.47 \mathrm{a}$ & $2.81 \mathrm{a}$ & $1611 \mathrm{a}$ & $84 \mathrm{a}$ & $122 \mathrm{a}$ & $43 \mathrm{a}$ & $18 \mathrm{a}$ \\
\hline
\end{tabular}

soil under CCs incorporated into the soil, irrespective of the cover crop species. The extractable $\mathrm{K}$ content in the high tunnel soils ranged from very low (40 and $42 \mathrm{mg} \mathrm{K} \mathrm{dm}^{-3}$, respectively, in the control soil and pea-oat $\mathrm{GM}$ treatment) to low $\left(88 \mathrm{mg} \mathrm{K} \mathrm{dm}^{-3}\right.$ of the pea GM soil). In general, the sufficient level of $\mathrm{K}$, determined by the universal soil test with acetate extraction, for most vegetables ranges from 150 to $250 \mathrm{mg} \mathrm{K} \mathrm{dm}^{-3}$ for high textured soil (Sady 2000). Soil phosphorus concentration was within the low range for vegetables ( $<30 \mathrm{mg} \mathrm{P} \mathrm{dm}^{-3}$ of soil) for the control and pea-treated soils, and within the optimal range for the pea-oat treatments.

In autumn 2016, after the romaine lettuce harvest, the concentrations of nutrient elements in the soils under the pea $\mathrm{CC}$ treatment were elevated, particularly for nitrogen $\left(43.18 \mathrm{mg} \mathrm{NH}_{4}-\mathrm{N}\right.$ and $\mathrm{NO}_{3}-\mathrm{N} \mathrm{dm}{ }^{-3}$ of soil), calcium, magnesium, and potassium (Table 6). In the second year after the $\mathrm{CC}$ treatments, the concentrations of mineral nitrogen determined in the soils after the green bean harvest were high and ranged from $45.57 \mathrm{mg} \mathrm{NH}_{4}-\mathrm{N}$ and

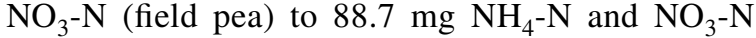
(pea-oat). A higher concentration of $\mathrm{P}$ in the soil after the green bean harvest was found in the peaoat CC treatment. The iceberg lettuce production in the high tunnel in autumn 2017 reduced the concentrations of soluble forms of macro-elements in the soil, especially those of $\mathrm{N}$ and $\mathrm{K}$ (Table 6).

After the tomato and romaine lettuce harvests in 2016, with the exception of B (low content), micronutrient concentrations were optimal for plant nutrition (Table 7). The highest B amount was found in the soil under the pea-oat treatments, irrespective of the methods of using CC residues (incorporating versus mulching). During the second cropping period (2017), the CC treatments slightly increased $\mathrm{Cu}$ and $\mathrm{Mn}$ concentrations in the high tunnel soil.

\section{Cash crop yielding}

Already before the first harvest of tomatoes, more leaves and female flowers were observed to appear on the control plants, which indicated an inhibitory 
Table 7 Microelement concentration ( $\mathrm{mg} \mathrm{kg}^{-1}$ of dry soil) in soils in the high tunnel after cover crop termination in 2016 and after cash crop harvest

\begin{tabular}{|c|c|c|c|c|c|}
\hline Treatment & $\mathrm{B}$ & $\mathrm{Cu}$ & $\mathrm{Fe}$ & Mn & $\mathrm{Zn}$ \\
\hline Autumn 2015 & 0.63 & 8.4 & 1696 & 212 & 50 \\
\hline \multicolumn{6}{|l|}{ Cover crop 2016} \\
\hline Control & $1.10 \mathrm{a}$ & $7.4 \mathrm{a}$ & $1920 \mathrm{a}$ & $224 \mathrm{a}$ & $63 \mathrm{a}$ \\
\hline Field pea & $1.22 \mathrm{a}$ & $7.1 \mathrm{a}$ & $1947 \mathrm{a}$ & $231 \mathrm{a}$ & $66 \mathrm{a}$ \\
\hline Pea-oat & $1.25 \mathrm{a}$ & $7.3 \mathrm{a}$ & $1966 \mathrm{a}$ & $225 \mathrm{a}$ & $67 \mathrm{a}$ \\
\hline \multicolumn{6}{|l|}{ Tomato 2016} \\
\hline Control & $0.15 \mathrm{ab}$ & $8.6 \mathrm{a}$ & 2559 a & $296 \mathrm{a}$ & $79 \mathrm{a}$ \\
\hline Field pea M & $0.13 \mathrm{a}$ & $7.4 \mathrm{a}$ & $2257 \mathrm{a}$ & $297 \mathrm{a}$ & $79 \mathrm{a}$ \\
\hline Field pea GM & $0.11 \mathrm{a}$ & $7.2 \mathrm{a}$ & 2398 a & $265 \mathrm{a}$ & $71 \mathrm{a}$ \\
\hline Pea-oat M & $0.21 \mathrm{c}$ & $8.1 \mathrm{a}$ & 2437 a & $291 \mathrm{a}$ & $84 \mathrm{a}$ \\
\hline Pea-oat GM & $0.18 \mathrm{bc}$ & $7.3 \mathrm{a}$ & $2250 \mathrm{a}$ & $256 \mathrm{a}$ & $75 \mathrm{a}$ \\
\hline \multicolumn{6}{|c|}{ Romaine lettuce 2016} \\
\hline Control & $0.38 \mathrm{a}$ & $6.8 \mathrm{a}$ & 1709 a & $156 \mathrm{a}$ & $54 \mathrm{a}$ \\
\hline Field pea & $0.30 \mathrm{a}$ & $6.7 \mathrm{a}$ & $1747 \mathrm{a}$ & $174 \mathrm{a}$ & $60 \mathrm{a}$ \\
\hline Pea-oat & $0.19 \mathrm{a}$ & $6.7 \mathrm{a}$ & 1698 a & $169 \mathrm{a}$ & $58 \mathrm{a}$ \\
\hline \multicolumn{6}{|l|}{ Green bean 2017} \\
\hline Control & $1.33 \mathrm{a}$ & $6.3 \mathrm{a}$ & 1998 a & $252 \mathrm{a}$ & $75 \mathrm{a}$ \\
\hline Field pea & $1.50 \mathrm{a}$ & $6.6 \mathrm{a}$ & $2012 \mathrm{a}$ & $261 \mathrm{a}$ & $79 a$ \\
\hline Pea-oat & $1.45 \mathrm{a}$ & $6.6 \mathrm{a}$ & 1983 a & $255 \mathrm{a}$ & $95 \mathrm{~b}$ \\
\hline \multicolumn{6}{|c|}{ Iceberg lettuce 2017} \\
\hline Control & $1.90 \mathrm{a}$ & $6.5 \mathrm{a}$ & $1515 \mathrm{a}$ & $219 \mathrm{a}$ & $55 \mathrm{a}$ \\
\hline Field pea & $2.18 \mathrm{a}$ & $7.1 \mathrm{~b}$ & $1557 \mathrm{a}$ & $234 \mathrm{c}$ & $57 \mathrm{a}$ \\
\hline Pea-oat & $2.19 \mathrm{a}$ & $7.3 \mathrm{~b}$ & 1529 a & $227 \mathrm{~b}$ & $56 \mathrm{a}$ \\
\hline
\end{tabular}

See Table 4 for explanation

effect of cover plants, especially where oat was involved. Harvesting of tomato fruit began on July 9 (control), July 13 (field pea), and July 18 (pea-oat). The yields of fruit $>4 \mathrm{~cm}$ in diameter were much higher where no green manure was used. As a result of the occurrence of viral diseases, the yields in the whole tunnel were not high and amounted to 4.60 $\mathrm{kg} \mathrm{m}^{-2}$, control; $2.46 \mathrm{~kg} \mathrm{~m}^{-2}$, field pea; and $2.15 \mathrm{~kg}$ $\mathrm{m}^{-2}$, pea-oat (Table 8 ). In the second growing season, the yield of green bean was significantly higher in the plot after field pea, whereas the yield of iceberg lettuce was higher in the control plot and after the pea-oat mixture. The quality of crops expressed by the amounts of dry matter, vitamin $\mathrm{C}$, and sugars in tomatoes and romaine lettuce grown in 2016 was at a similar level (Table 8). Despite the lack of statistically significant differences, one can notice a tendency for those contents to decrease in the edible parts obtained after the pea-oat mixture. In the second year of the
Table 8 Selected yield parameters for cash crop plants in the organically managed tunnel in 2016-2017

\begin{tabular}{|c|c|c|c|c|}
\hline Treatment & $\begin{array}{l}\text { Yield (kg } \\
\left.\mathrm{m}^{-2}\right)\end{array}$ & d.m. (\%) & $\begin{array}{l}\text { Vitamin C } \\
\text { (mg } 100 \\
\text { f.m.) }\end{array}$ & Sugars $(\%)$ \\
\hline \multicolumn{5}{|c|}{ Tomato 2016} \\
\hline Control & $4.60 \mathrm{~b}$ & $6.28 \mathrm{a}$ & $24.2 \mathrm{a}$ & $3.26 \mathrm{~b}$ \\
\hline $\begin{array}{r}\text { Field } \\
\text { pea }\end{array}$ & $2.46 \mathrm{a}$ & $6.19 \mathrm{a}$ & $24.2 \mathrm{a}$ & $2.89 \mathrm{a}$ \\
\hline Pea-oat & $2.15 \mathrm{a}$ & $6.03 \mathrm{a}$ & $22.2 \mathrm{a}$ & $3.02 \mathrm{ab}$ \\
\hline \multicolumn{5}{|c|}{ Romaine lettuce 2016} \\
\hline Control & $1.50 \mathrm{a}$ & $6.30 \mathrm{a}$ & $26.5 \mathrm{a}$ & $0.13 \mathrm{a}$ \\
\hline $\begin{array}{r}\text { Field } \\
\text { pea }\end{array}$ & $1.25 \mathrm{a}$ & $6.57 \mathrm{a}$ & $25.6 \mathrm{a}$ & $0.13 \mathrm{a}$ \\
\hline Pea-oat & $1.37 \mathrm{a}$ & $6.01 \mathrm{a}$ & $24.2 \mathrm{a}$ & $0.13 \mathrm{a}$ \\
\hline \multicolumn{5}{|c|}{ Green bean 2017} \\
\hline Control & $2.54 \mathrm{a}$ & $9.83 \mathrm{~b}$ & - & $1.94 \mathrm{a}$ \\
\hline $\begin{array}{r}\text { Field } \\
\text { pea }\end{array}$ & $2.97 \mathrm{~b}$ & $9.84 \mathrm{~b}$ & - & $2.01 \mathrm{a}$ \\
\hline Pea-oat & $2.52 \mathrm{a}$ & $9.55 \mathrm{a}$ & - & $1.95 \mathrm{a}$ \\
\hline \multicolumn{5}{|c|}{ Iceberg lettuce 2017} \\
\hline Control & $5.88 \mathrm{a}$ & $4.22 \mathrm{a}$ & $15.9 \mathrm{a}$ & $1.26 \mathrm{a}$ \\
\hline $\begin{array}{r}\text { Field } \\
\text { pea }\end{array}$ & $4.50 \mathrm{a}$ & $4.49 \mathrm{a}$ & $15.8 \mathrm{a}$ & $1.30 \mathrm{a}$ \\
\hline Pea-oat & $5.23 \mathrm{a}$ & $4.20 \mathrm{a}$ & $17.6 \mathrm{~b}$ & $1.38 \mathrm{a}$ \\
\hline
\end{tabular}

See Table 4 for explanation

study, when the biomass of the ground cover plants had been largely mineralized, a significantly lower dry matter content was found in the green bean plants grown after the pea-oat mixture. The mineralized plant residues of field pea caused an increase in the dry matter content in iceberg lettuce. The level of vitamin $\mathrm{C}$ in iceberg lettuce was significantly higher in the case of cultivation in the plot after the pea-oat mixture. The sugar content in the vegetables grown in the second year after the cover plants showed a slight positive effect of these treatments.

Foliar analysis showed that all leaf macronutrient concentrations except $\mathrm{K}$ in pea GM and pea-oat GM treatments, $\mathrm{Mg}$ in the control, and sulfur were in the range considered below optimal for commercially grown tomato (Sainju et al. 2003). Generally, cover cropping lowered $\mathrm{Ca}, \mathrm{Mg}$, and $\mathrm{S}$ content in tomato leaves, compared with the control plants. With the exception of plants grown in the plots where residues of CCs were used as organic mulch, the concentrations of potassium and phosphorus in tomato leaves were higher than in the control ones. This can indicate that 
organic CC residue incorporated into the soil decomposed easily, becoming a good source of available $\mathrm{K}$ and $\mathrm{P}$ for tomato plants. The concentration of these elements in plant tissues is also linked with the higher available soil $\mathrm{K}$ and $\mathrm{P}$ (only for pea-oat GM treatment) in the treatments with CCs as green manure (GM).

The highest $\mathrm{N}$ concentration in tomato leaves in August was determined in the pea GM treatment with residues incorporated into the soil (Table 9). The soil mulched with pea-oat residues reduced tomato leaf $\mathrm{N}$ accumulation and tomato fruit yield, relative to the control and the other treatments. Generally, cover cropping lowered the concentrations of micronutrients in tomato leaves in relation to the control soil. The exception was the high
$\mathrm{B}$ and Mo contents in the tomato leaves growing in the plots where the mulch of field pea was used (Table 9). A significantly higher concentration of K was found in tomato fruits harvested from the plots with CC treatments, in comparison with the control (Table 10). Potassium and phosphorus concentrations in fruits were higher in the mulched plots, irrespective of the CC species. A similar tendency was observed for boron and manganese.

Leaf analyses of green bean plants planted in the high tunnel in the second year of the study showed that the effects of field pea and pea-oat cover crops in rotation on subsequent nutrient dynamics were mostly short-lived. For all the nutrients, with the exception of $\mathrm{N}$ and $\mathrm{B}$, the concentrations in legume
Table 9 Nutrient concentration in the leaves of organically managed tomato in the high tunnel, 2016

See Table 4 for explanation

Table 10 Nutrient concentration in the fruit of organically managed tomato in the high tunnel, 2016

See Table 4 for explanation

\begin{tabular}{|c|c|c|c|c|c|c|}
\hline \multicolumn{7}{|c|}{ Macronutrients (\% d.m.) } \\
\hline Treatment & $\mathrm{N}$ & $\mathrm{Ca}$ & $\mathrm{K}$ & $\mathrm{Mg}$ & $\mathrm{P}$ & $S$ \\
\hline Control & $2.04 \mathrm{bc}$ & $4.44 \mathrm{c}$ & $1.84 \mathrm{a}$ & $0.43 \mathrm{c}$ & $0.18 \mathrm{a}$ & $1.02 \mathrm{c}$ \\
\hline Field pea M & $2.00 \mathrm{~b}$ & $4.02 \mathrm{bc}$ & $1.94 \mathrm{a}$ & $0.38 \mathrm{bc}$ & $0.19 \mathrm{ab}$ & $0.89 \mathrm{c}$ \\
\hline Field pea GM & $2.49 \mathrm{~d}$ & $2.57 \mathrm{a}$ & $2.91 \mathrm{~b}$ & $0.27 \mathrm{a}$ & $0.20 \mathrm{ab}$ & $0.54 \mathrm{a}$ \\
\hline Pea-oat M & $1.71 \mathrm{a}$ & $3.43 \mathrm{~b}$ & $1.83 \mathrm{a}$ & $0.34 \mathrm{~b}$ & $0.18 \mathrm{a}$ & $0.66 \mathrm{ab}$ \\
\hline Pea-oat GM & $2.23 \mathrm{c}$ & $3.43 \mathrm{~b}$ & $2.55 \mathrm{~b}$ & $0.36 \mathrm{~b}$ & $0.22 \mathrm{c}$ & $0.71 \mathrm{~b}$ \\
\hline \multicolumn{7}{|c|}{ Micronutrients (mg kg ${ }^{-1}$ d.m.) } \\
\hline Treatment & $\mathrm{B}$ & $\mathrm{Cu}$ & $\mathrm{Fe}$ & $\mathrm{Mn}$ & Mo & $\mathrm{Zn}$ \\
\hline Control & $58 \mathrm{~d}$ & $9.6 \mathrm{bc}$ & $113 \mathrm{~b}$ & $100 \mathrm{c}$ & $0.58 \mathrm{a}$ & $35 \mathrm{~b}$ \\
\hline Field pea M & $53 \mathrm{~cd}$ & $10.2 \mathrm{c}$ & $110 \mathrm{~b}$ & $71 \mathrm{~b}$ & $1.22 \mathrm{c}$ & $26 \mathrm{a}$ \\
\hline Field pea GM & $28 \mathrm{a}$ & $6.9 \mathrm{a}$ & $89 a$ & $48 \mathrm{a}$ & $0.61 \mathrm{a}$ & $21 \mathrm{a}$ \\
\hline Pea-oat M & $42 \mathrm{bc}$ & $7.4 \mathrm{a}$ & $81 \mathrm{a}$ & $68 \mathrm{ab}$ & $0.78 \mathrm{ab}$ & $25 \mathrm{a}$ \\
\hline Pea-oat GM & $38 \mathrm{ab}$ & $8.2 \mathrm{ab}$ & $96 \mathrm{ab}$ & $59 \mathrm{ab}$ & $1.04 \mathrm{bc}$ & $34 \mathrm{~b}$ \\
\hline
\end{tabular}

\begin{tabular}{lllllll}
\hline Macronutrients (\% d.m.) & \multicolumn{7}{l}{} \\
\hline Treatment & $\mathrm{Ca}$ & $\mathrm{K}$ & $\mathrm{Mg}$ & $\mathrm{P}$ & $\mathrm{S}$ & $\mathrm{Na}$ \\
Control & $78 \mathrm{a}$ & $2592 \mathrm{a}$ & $44 \mathrm{a}$ & $142 \mathrm{a}$ & $0.06 \mathrm{a}$ & $10.8 \mathrm{a}$ \\
Field pea M & $89 \mathrm{a}$ & $2904 \mathrm{ab}$ & $62 \mathrm{bc}$ & $207 \mathrm{~b}$ & $0.08 \mathrm{bc}$ & $15.3 \mathrm{a}$ \\
Field pea GM & $87 \mathrm{a}$ & $3146 \mathrm{~b}$ & $50 \mathrm{ab}$ & $180 \mathrm{ab}$ & $0.07 \mathrm{ab}$ & $13.2 \mathrm{a}$ \\
Pea-oat M & $80 \mathrm{a}$ & $4199 \mathrm{c}$ & $68 \mathrm{c}$ & $269 \mathrm{c}$ & $0.09 \mathrm{c}$ & $15.2 \mathrm{a}$ \\
Pea-oat GM & $82 \mathrm{a}$ & $3288 \mathrm{~b}$ & $51 \mathrm{ab}$ & $192 \mathrm{ab}$ & $0.07 \mathrm{ab}$ & $12.4 \mathrm{a}$ \\
Micronutrients (mg kg-1 d.m.) & & & & & \\
Treatment & $\mathrm{B}$ & $\mathrm{Cu}$ & $\mathrm{Fe}$ & $\mathrm{Mn}$ & $\mathrm{Mo}$ & $\mathrm{Zn}$ \\
Control & $0.21 \mathrm{a}$ & $0.40 \mathrm{a}$ & $2.41 \mathrm{a}$ & $0.43 \mathrm{a}$ & $0.03 \mathrm{a}$ & $0.83 \mathrm{a}$ \\
Field pea M & $0.25 \mathrm{c}$ & $0.58 \mathrm{~b}$ & $3.37 \mathrm{a}$ & $0.95 \mathrm{~b}$ & $0.05 \mathrm{a}$ & $1.25 \mathrm{a}$ \\
Field pea GM & $0.23 \mathrm{~b}$ & $0.50 \mathrm{ab}$ & $3.04 \mathrm{a}$ & $0.63 \mathrm{ab}$ & $0.04 \mathrm{a}$ & $0.95 \mathrm{a}$ \\
Pea-oat M & $0.29 \mathrm{~d}$ & $0.60 \mathrm{~b}$ & $3.18 \mathrm{a}$ & $0.91 \mathrm{~b}$ & $0.02 \mathrm{a}$ & $1.17 \mathrm{a}$ \\
Pea-oat GM & $0.24 \mathrm{bc}$ & $0.55 \mathrm{ab}$ & $3.17 \mathrm{a}$ & $0.77 \mathrm{ab}$ & $0.02 \mathrm{a}$ & $1.29 \mathrm{a}$ \\
\hline
\end{tabular}


plant tissues were similar regardless of the prior $\mathrm{CC}$ treatment. In the second year, the field pea treatment slightly decreased $\mathrm{N}$ and $\mathrm{B}$ concentrations in green bean leaves (Table 11).

In contrast to the leaves, green bean pods harvested from the plots under prior $\mathrm{CC}$ treatments had significantly higher $\mathrm{K}$ and $\mathrm{P}$ concentrations in relation to the control plants (Table 12). Also, the highest Mn content was found in pods following the field pea treatment, in comparison with the control and pea-oat treatment. The reverse was true for the molybdenum concentration in green been pods.

\section{Discussion}

In this trial, we surveyed management strategies that included a cover crop system and vegetable crop rotation in a high tunnel during cropping periods 2016-2017 with a sequence of plants: spring field pea (pea-oat mixture/tomato/romaine lettuce/green bean/ iceberg lettuce. Some species grow poorly in monocultures, but cooperate positively with other species in mixtures, for example, grass-legume interactions (Sainju et al. 2005; Forest et al. 2011). This regularity confirms our results with pea-oat bicultural as well as the research by Campigila et al. (2012) for vetchoat mixture. Conversely, during a short growing season of a hairy vetch and wild oat mixture cover crop, Araki (2009) did not observe biomass to be greater than in the monoculture of wild oat. Neugschwandtner and Kaul (2014) demonstrated that oat-pea intercrops could not achieve higher yields than the corresponding pure stands on a fertile soil.

In this experiment, the field pea and field pea-oat mixtures grown in early spring in unheated high tunnel had aboveground biomass comparable to or higher than that in other regions of Poland in autumn open field conditions (Jabłońska-Ceglarek and Rosa 2002; Zaniewicz-Bajkowska et al. 2012). Moreover, relatively low temperatures during the times of $\mathrm{CC}$ establishment in the spring and biomass production in February to April likely favored the growing of oat over the field pea. In the study by Neugschwandtner and Kaul (2014), oat was the dominant partner in the mixtures, strongly outcompeting pea. The authors concluded that the sowing
Table 11 Nutrient concentration in the leaves of organically managed green bean in the high tunnel, 2017

See Table 4 for explanation

Table 12 Nutrient concentration in the pods of organically managed green bean in the high tunnel, 2017

See Table 4 for explanation

\begin{tabular}{|c|c|c|c|c|c|c|}
\hline \multicolumn{7}{|c|}{ Macronutrients (\% d.m.) } \\
\hline Treatment & $\mathrm{N}$ & $\mathrm{Ca}$ & $\mathrm{K}$ & $\mathrm{Mg}$ & $\mathrm{P}$ & $\mathrm{S}$ \\
\hline Control & $4.03 \mathrm{~b}$ & $3.72 \mathrm{a}$ & $2.81 \mathrm{a}$ & $0.44 \mathrm{a}$ & $0.31 \mathrm{~b}$ & $0.25 \mathrm{a}$ \\
\hline Field pea & $3.76 \mathrm{a}$ & $4.14 \mathrm{a}$ & $2.62 \mathrm{a}$ & $0.47 \mathrm{a}$ & $0.27 \mathrm{a}$ & $0.23 \mathrm{a}$ \\
\hline Pea-oat & $4.01 \mathrm{~b}$ & $3.94 \mathrm{a}$ & $2.89 \mathrm{a}$ & $0.43 \mathrm{a}$ & $0.30 \mathrm{~b}$ & $0.24 \mathrm{a}$ \\
\hline \multicolumn{7}{|c|}{ Micronutrients (mg kg ${ }^{-1}$ d.m.) } \\
\hline & $\mathrm{B}$ & $\mathrm{Cu}$ & $\mathrm{Fe}$ & Mn & Mo & $\mathrm{Zn}$ \\
\hline Control & $14.8 \mathrm{~b}$ & $11.2 \mathrm{a}$ & 29 a & $43 \mathrm{a}$ & $1.87 \mathrm{a}$ & $51 \mathrm{a}$ \\
\hline Field pea & $12.1 \mathrm{a}$ & $10.7 \mathrm{a}$ & $26 \mathrm{a}$ & $43 \mathrm{a}$ & $2.96 \mathrm{a}$ & $47 \mathrm{a}$ \\
\hline Pea-oat & $13.9 \mathrm{~b}$ & $10.4 \mathrm{a}$ & $26 \mathrm{a}$ & $41 \mathrm{a}$ & $2.67 \mathrm{a}$ & $50 \mathrm{a}$ \\
\hline
\end{tabular}

\begin{tabular}{|c|c|c|c|c|c|c|}
\hline \multicolumn{7}{|c|}{ Macronutrients ( $\mathrm{mg} \mathrm{kg}^{-1}$ f.m.) } \\
\hline Treatment & $\mathrm{N}$ & $\mathrm{Ca}$ & $\mathrm{K}$ & $\mathrm{Mg}$ & $\mathrm{P}$ & $S$ \\
\hline Control & $268 \mathrm{a}$ & $431 \mathrm{a}$ & $1776 \mathrm{a}$ & $169 \mathrm{a}$ & $326 \mathrm{a}$ & $146 \mathrm{a}$ \\
\hline Field pea & $272 \mathrm{a}$ & $437 \mathrm{a}$ & 1944 c & $157 \mathrm{a}$ & $364 \mathrm{~b}$ & $150 \mathrm{a}$ \\
\hline Pea-oat & $263 \mathrm{a}$ & $440 \mathrm{a}$ & $1851 \mathrm{~b}$ & $155 \mathrm{a}$ & $356 \mathrm{~b}$ & $151 \mathrm{a}$ \\
\hline \multicolumn{7}{|c|}{ Micronutrients (mg kg${ }^{-1}$ f.m.) } \\
\hline & $\mathrm{B}$ & $\mathrm{Cu}$ & $\mathrm{Fe}$ & $\mathrm{Mn}$ & Mo & $\mathrm{Zn}$ \\
\hline Control & $1.18 \mathrm{a}$ & $0.78 \mathrm{a}$ & $4.86 \mathrm{a}$ & $1.50 \mathrm{a}$ & $0.57 \mathrm{~b}$ & $3.50 \mathrm{a}$ \\
\hline Field pea & $1.05 \mathrm{a}$ & $0.77 \mathrm{a}$ & $5.15 \mathrm{a}$ & $1.77 \mathrm{~b}$ & $0.36 \mathrm{a}$ & $3.71 \mathrm{a}$ \\
\hline Pea-oat & $1.10 \mathrm{a}$ & $0.81 \mathrm{a}$ & $5.07 \mathrm{a}$ & $1.56 \mathrm{a}$ & $0.57 \mathrm{~b}$ & $3.65 \mathrm{a}$ \\
\hline
\end{tabular}


ratio and fertilization affected the yield component parameters of oat and pea compared to the corresponding pure stands. In the presented study, the sowing ratio for pea in the mixture with oat was 120:90 in kilogram of seed per hectare.

The pea monoculture had lower fresh biomass than the pea-oat mixture, and the $\mathrm{N}$ content in their biomass was $155 \mathrm{~kg} \mathrm{~N} \mathrm{ha}^{-1}$ and $136 \mathrm{~kg} \mathrm{~N} \mathrm{ha}^{-1}$, respectively. In the study by Ranells and Wagger (1997), N accumulation values for the legume component followed the ranking winter pea $>$ hairy vetch $>$ common vetch $>$ crimson clover, and ranged from 24 to $93 \mathrm{~kg}$ $\mathrm{N} \mathrm{ha}^{-1}$. Grass factor $\mathrm{N}$ content ranged from 18 to 39 $\mathrm{kg} \mathrm{N} \mathrm{ha}^{-1}$ in the order rye $>$ oat $>$ wheat. In the study by Jabłońska-Ceglarek and Rosa (2002), N accumulation in the biomass $\left(20 \mathrm{t} \mathrm{f.m.} \mathrm{ha}{ }^{-1}\right.$ ) of field pea+oat in mixed cultivation amounted to $72 \mathrm{~kg} \mathrm{~N} \mathrm{ha}^{-1}$.

In our study, we examined the effect/sequence effect of spring cover crops and two different methods of managing the cover plant biomass (left on the soil surface as a mulch or incorporated into the soil) on soil and plant quality parameters in organic high tunnel production. This is important to recognize the benefits of this system beyond yield which justify the adoption of CCs by farmers. In this study, cover crop improved some of important soil properties examined, including bulk density, organic matter content, and water-stable aggregate index compared to the control soil. The fertility of soil significantly depends on its compactness, which impacts the agronomic yield. The tendency for a lower bulk density attribute in the soils under a cover crop treatment persisted after the romaine lettuce harvest in 2016 and at the end of 2017, particularly for the pea-oat mix. This confirms the results of the study by Haruna and Nkongolo (2015) which indicated a 3.5\% decrease in soil bulk density in cover crop plots as compared with no-cover crop soils. Similarly, Gabriel et al. (2017) found a positive cover crop effect consisting in an increase in soil micro- and macro-porosity. That study also showed an improvement in water retention in 20 intermediate layers of the soil profile. Nascente and Stone (2018) after 2 years (two cycles of cover crops) also promoted improvement in soil physical properties in the two soil layers $0.06-0.10 \mathrm{~m}$ and $0.11-0.20 \mathrm{~m}$.

Schipanski et al. (2014) and McDaniel et al. (2014) showed that cover cropping increased soil $\mathrm{C}$ sequestration. Poeplau and Don (2015), during an observation period of up to 54 years, indicated that the cover crop was correlated with SOC content change, with an annual variation rate of $0.32 \pm 0.08 \mathrm{Mg} \mathrm{ha}^{-1} \mathrm{yr}^{-1}$ in 22 $\mathrm{cm}$ of soil depth. In the presented study, after the cover crop termination (2016), the highest soil organic carbon (SOC) content was determined in the soils under the cover crop treatment. In the subsequent cropping season (2017), the trend of an increasing SOC content in the soils under cover crop treatment was still clearly evident. The highest SOC values were noted for the soils treated with the pea-oat mixture. Our results confirmed that the quantity and quality ( $\mathrm{C} / \mathrm{N}$ ratio) of crop residues returned to the soil regulate SOC sequestration. Soil amendment with bio-labile organic inputs has short-term effects on soil chemical and physical attributes (Spaccini and Piccolo 2013). Generally, mineral nitrogen availability for organic matter decomposition is responsible for a faster and more advanced decomposition (Coppens et al. 2007).

Soil aggregation, as well as soil structure, is essential for soil functioning and productivity. In both years of our experiment, the highest water-stable aggregate index was found in the soils under the field pea-oat mixture treatment. Spaccini and Piccolo (2013) had indicated that enriching the soil with bio-labile organic matter had short-term effects on soil aggregation processes, and that soil treatments with humified organic materials might considerably improve aggregate stability. This may explain the relatively poorest results obtained for the field pea monoculture treatment. However, soil structure analysis conducted in 2016 showed an increase in the water stability index for both cover crop treatments on the tomato plots in comparison with the untreated soil (Table 4). By conducting the 2-year experiment, we demonstrated that rotation and/or cover crop treatment can maintain suitable physical and chemical soil properties through macroaggregate water stabilization, which contributes to protecting SOC stocks and a stable soil structure. Particle size analysis (PN-R-04032 1998) classified the soil at this site as fine-grained, belonging to the silty clay group with clay particles constituting about $40 \%$. A high amount of clay particles as well as high level of bivalent cations ( $>1000 \mathrm{mg} \mathrm{Ca}$ and $>100 \mathrm{mg} \mathrm{Mg} \mathrm{dm}^{-3}$ of soil) in the analyzed soils determined a high percentage of water-stable soil aggregates. Bivalent cations improve soil structure by binding clay particles and soil organic matter (Bronic and Lal 2005). The growth in macroaggregate formation can be explained with the root and microbial 
biomass production and the presence of root debris and microbial bio-products, which promote the association of microaggregates into meso- and macroaggregates (Wohlenberg et al. 2004; Spaccini and Piccolo 2013; Ontl et al. 2015). Ontl et al. (2015) suggest that the formation of macroaggregates can be a good indicator of potential future $\mathrm{C}$ stabilization due to their significance for protecting freshly deposited SOM and helping the formation of stable organomineral complexes. Macroaggregates are formed around fresh organic residues, which are subsequently integrated and become coarse intra-aggregate particulate organic matter (Bronic and Lal 2005).

For nutrient management in organic high tunnel systems, the effects of organic matter and soil nutrient cycling are crucial points (Rudisill et al. 2015). Moreti et al. (2007) reported that cover crops could significantly affect the soil chemical attributes. Our results confirm the effect found by Fatima et al. (2012), who determined a $28 \%$ higher potassium content in vetch-treated soil than in bare soil. Plants can modify nutrient availability by secreting numerous chemicals from their roots (root exudates). These exudates alter nutrient mobility through various mechanisms such as ion exchange, chemical desorption, or complexation (Hinsinger et al. 2005). $\mathrm{N}_{2}$-fixing legumes, which can grow without nitrate uptake from the soil solution, but via the profits of $\mathrm{N}_{2}$ reduction in the root nodules, must secrete an excess of protons. These protons can markedly lower rhizosphere $\mathrm{pH}$ and can increase the availability of some mineral nutrients in the soil (Dakora and Phillips 2002; Sugiyama and Yazaki 2012). In our study, this phenomenon was observed for $\mathrm{Ca}, \mathrm{Mg}, \mathrm{K}$, and $\mathrm{P}$ in the $\mathrm{CC}$ plots (only under the pea-oat treatment). In the study of Nascente and Stone (2018) in open field conditions, cover crops alone provided no changes in soil chemical properties. However, the rotation cover crops/cash crops/cover crops/cash crops decreased $\mathrm{pH}$ values, and increased $\mathrm{Ca}, \mathrm{Mg}, \mathrm{K}$, and $\mathrm{Fe}$ contents in the soil.

Cover cropping did not modify the availability of micronutrients in the high tunnel soils analyzed after CC plant termination (Table 7), which had been expected. Variation in the concentration of trace elements in plant leaves during cultivation can indicate their different availability to plants from the experimental plots. A probable explanation for this could be the method of soil extraction. The extractable forms of trace metals, including micronutrients, were measured in $1 \mathrm{~mol} \mathrm{dm}^{-3} \mathrm{HCl}$ soil extract (Ostrowska et al. 1991). This technique with a relatively "aggressive extractant" removes more than the soluble, exchangeable, and weakly adsorbed fractions of trace elements. This soil extractant and procedure is currently used to estimate the availability and critical levels for micronutrient cations in Poland.

Cover crops affect subsequent crop yield mainly through their influence on nitrogen availability. In our study, the nitrate content in the soil had been depleted of the available $\mathrm{N}$ reserve by the cover crops. The inhibitory effect of cover plants, especially for pea-oat mixture, was observed for tomato plants which were transplanted into the high tunnel directly after pea and pea-oat termination. However, in the second growing season, the yield of green bean was significantly higher in the plot after field pea. Cover crops can improve nutrient use efficiency when the elements in the cover crops are cycled back into the soil as green manure and are taken from the soil by subsequent cash crops (Ruffo and Bollero 2003; Araki 2009; Jabłońska-Ceglarek and Rosa 2002). The chemical composition of the residues has an important impact on the decomposition processes. Araki (2009) had shown higher marketable yields of high tunnel tomato in hairy vetch plots than in those with mineral fertilization and control plots. Similar results had been obtained by Sainju et al. (2003) and Sugihara et al. (2013). The $\mathrm{C} / \mathrm{N}$ ratio is often used as an indicator of either net $\mathrm{N}$ mineralization or immobilization during residue decomposition. In the Araki (2009) study with the $15 \mathrm{~N}$-labelling method, hairy vetch residues incorporated into the soil in greenhouse conditions decomposed rapidly for about 1 month and the $\mathrm{N}$ released from green manure was absorbed by tomato plants. This demonstrated that pea residues in the presented study can provide a substantial level of $\mathrm{N}$ to the subsequent tomato crop. Decomposition of cereal residues immobilizes soil $\mathrm{N}$ near the soil surface, which can suppress tomato growth. Araki (2009) and Fatima et al. (2012) found the highest $\mathrm{N}$ content in the tomato leaves produced with a hairy vetch monoculture cover crop. As mentioned earlier, the nitrogen concentration in plant residues is the main factor determining residue quality due to the influence of $\mathrm{N}$ availability on microbial metabolism (Coppens et al. 2007; Jani et al. 2016). A lower initial C/N ratio of a legume cover crop than that of non-legume or mixed crop residues favors the mineralization of nutrients 
for their uptake by plants (Rosecrance et al. 2000; Lawson et al. 2015).

In the presented study, in the soil covered with mown CC plants, the tomato plants developed and grew more slowly in relation to the control plants. Gent (1992) had demonstrated that earlier tomato plantings suffered from nutrient deficiencies, presumably as a result of soil low-temperature effects on nutrient uptake. The reason for the large differences in tomato yielding between CCs plots and the control may have been the positive influence of black film on soil moisture and temperature, and the increased availability of nutrients in the plots not sown with the cover plants. Knowledge of these relationships could permit development of more precise cover crop practices in organic high tunnel production, where the success of this solution largely depends on the proper establishment and management of CC biomass.

In 2017, after green bean harvest, we found the significantly higher soil $\mathrm{Ca}, \mathrm{Mg}$, and $\mathrm{P}$ concentration in pea-oat field compared to the control soil. Additionally, higher concentrations of $\mathrm{N}^{-\mathrm{NO}_{3}}$ in cover pea-oat cropping soils were observed in relation to pea treatment. Green bean pods collected from the plots under prior pea-oat treatments had significantly higher $\mathrm{K}$ and $\mathrm{P}$ concentrations in relation to the control and pea treatment plants. The green bean legume plant represents a tripartite symbiotic relationship where diazotrophic bacteria (Rhizobium) fix $\mathrm{N}$ not only for the host plant but also for mycorrhizal fungi. This is particularly important in the uptake of nutrients required by plants living in a soil environment that is low in available nutrients. Legume plants establish symbiotic interactions with rhizobia and arbuscular mycorrhizal fungi to obtain several nutrients such as nitrogen and phosphates (Sugiyama and Yazaki 2012). Organic acids from legume root exudates can also solubilize unavailable soil $\mathrm{Ca}, \mathrm{Fe}$, and $\mathrm{Al}$ phosphates (Dakora and Phillips 2002). This may explain the increase in some available macronutrients in soil after growing pea-oat plants in our experiment (Table 6).

Interesting interactions between the cover crops and the tomato plant in the high tunnel organic production resulting in delayed leaf senescence and increased fungal disease tolerance were observed. This is in agreement with the results of studies by Kumar et al. (2005) and Fatima et al. (2012). Thus, a greater K concentration in CC-amended soils, and in the tomato leaves and fruit harvested from those plots, could be responsible for delayed leaf senescence. Potassium is essential for most of the biochemical and physiological plant processes and influences plant growth and metabolism. Deficiency of potassium may intensify early leaf senescence, probably via stimulation of ethylene biosynthesis (Wang et al. 2013).

\section{Conclusions}

There are many good reasons to use cover crops in sustainable horticulture. To understand how cover cropping management affects vegetable production in an unheated organic high tunnel, this experiment investigated the effect of rotation and spring cover crops (pea monoculture and pea-oat biculture) on physicochemical soil properties and on yield and its quality. Our results revealed an increase in soil $\mathrm{pH}$ and in the availability of some mineral nutrients in the soil under $\mathrm{CC}$ treatments, especially $\mathrm{Ca}, \mathrm{Mg}, \mathrm{K}$, and P. Obtained results suggest that cover crops should be included in the agricultural practices in organic high tunnels so that they can be used to protect soil quality. However, there may be instances when water and nutrient use by cover crops or field operations associated with CC management could decrease cash crop yield in high tunnels, and local knowledge of these risks will need to be taken into account. In the presented study, early spring cover crops delivered no benefit to the subsequent summer crop. Significant differences between $\mathrm{CC}$ species and the method of using the biomass of green manure were observed. $\mathrm{N}$ uptake by the subsequent cash crop was greater with pea monoculture than with pea-oat-biculture and in the green manure formula with residues incorporated into the soil than being used as mulch. Because of the higher $\mathrm{N}$ content in the biomass, field pea cover crops may increase $\mathrm{N}$ uptake by the summer crop, compared to pea-oat CC. However, the potential of field pea $\mathrm{CC}$ to improve yield in the high tunnel was observed by us only in the second-year cash crop yield (green bean). Further research and extension efforts are required for adaptation of cover cropping in crop rotation practices to organic tunnels, to facilitate greater application at the farm level.

Acknowledgements The research at the University of Agriculture in Krakow was subvented by the Polish Ministry of Science and Higher Education in 2020. 
Author contribution Iwona Domagała-Świątkiewicz: conceptualization, formal analysis, investigation, writing (original draft), visualization, project administration. Piotr Siwek: conceptualization, methodology, resources, writing (review and editing).

\section{Declarations}

Conflict of interest The authors declare no competing interests.

Open Access This article is licensed under a Creative Commons Attribution 4.0 International License, which permits use, sharing, adaptation, distribution and reproduction in any medium or format, as long as you give appropriate credit to the original author(s) and the source, provide a link to the Creative Commons licence, and indicate if changes were made. The images or other third party material in this article are included in the article's Creative Commons licence, unless indicated otherwise in a credit line to the material. If material is not included in the article's Creative Commons licence and your intended use is not permitted by statutory regulation or exceeds the permitted use, you will need to obtain permission directly from the copyright holder. To view a copy of this licence, visit http://creativecommons.org/licenses/by/4.0/.

\section{References}

Araki H (2009) Tomatoes production with cover crops in greenhouse. Hortic Environ Biote 50:324-328

Bronic CJ, Lal R (2005) Soil structure and management: a review. Geoderma 124:3-22

Campigila E, Radicetti E, Mancinelli R (2012) Weed control strategies and yield response in a pepper crop (Capsicum annuит L.) mulched with hairy vetch (Vicia villosa Roth.) and oat (Avena sativa L.) residues. Crop Prot 33:65-73

Coppens F, Garnier P, Findeling A, Merckx R, Recous S (2007) Decomposition of mulched versus incorporated crop residues: modelling with PASTIS clarifies interactions between residue quality and location. Soil Biol Biochem 39:2339-2350

Dakora FD, Phillips DA (2002) Root exudates as mediators of mineral acquisition in low-nutrient environments. Plant Soil 245:35-47

Gabriel JL, Quemada M, Martín-Lammerding D, Vanclooster M (2017) Assessing the cover crop effect on soil hydraulic properties by inverse modelling in a 10-year field trial. Hydrol Earth Sys Sc. https://doi.org/10.5194/ hess-2017-643

Gieske MF, Ackroyd VJ, Baas DG, Mutch DR, Wyse DL, Durgan BR (2016) Brassica cover crop effects on nitrogen availability and oat and corn yield. Agron J 108:151-161

Fatima T, Teasdale JR, Bunce J, Mattoo AK (2012) Tomato response to legume cover crop and nitrogen: differing enhancement patterns of fruit yield, photosynthesis and gene expression. Funct Plant Biol 39(3):246-254
Forest I, Calcagno V, Hector A, Connolly J, Harpole WS, Reich PB, Scherer-Lorenzen M et al (2011) High plant diversity is needed to maintain ecosystem services. Nature 477:199-202

Hartwig NL, Ammon HU (2002) Cover crops and living mulches. Weed Sci. 50:688-699

Haruna SI, Nkongolo NV (2015) Cover crop management effects on soil physical and biological properties. Procedia Environ Sci 29:13-14

Hecher EAD, Falk CL, Steven JE, Guldan SJ, Uchanski ME (2014) The economics of low-cost high tunnels for winter vegetable production in the southwestern United States. HortTechnol 24:7-14

Hinsinger P, Gobran GR, Gregory PJ, Wenzel WW (2005) Rhizosphere geometry and heterogeneity arising from root-mediated physical and chemical processes. New Phytol 168:293-303

Jabłońska-Ceglarek R. Rosa R (2002) Influence of different forms of organic fertilization on cropping and chemical composition of white cabbage. Acta Sci Pol-Hortu 1(2) 2:25-32

Jani A, Grossman J, Smyth T, Hu S (2016) Winter legume cover-crop root decomposition and $\mathrm{N}$ release dynamics under disking and roller-crimping termination approaches. Renew Agric Food Sys 31:214-229

Janke RR, Altamimi ME, Khan M (2017) The use of high tunnels to produce fruit and vegetable crops in North America. Agri Sci 8:692-715

Kaye JP, Quemada M (2017) Using cover crops to mitigate and adapt to climate change: a review. Agron Sustain Dev 37. https://doi.org/10.1007/s13593-016-0410-x

Kołota E, Adamczewska-Sowińska K (2013) Living mulches in vegetables crops production: perspectives and limitations. A review. Acta Sci Pol-Hortu 12:127-142

Kumar V, Abdul-Baki A, Anderson JD, Mattoo AK (2005) Cover crop residues enhance growth, improve yield, and delay leaf senescence in greenhouse-grown tomatoes. Hort Sci 40(5):1307-1311

Lawson A, Cogger C, Bary A, Fortuna AM (2015) Influence of seeding ratio, planting date, and termination date on rye-hairy vetch cover crop mixture performance under organic management. PLoS ONE 10. https://doi.org/10. 1371/journal.pone.0129597

McDaniel MD, Grandy AS, Tiemann LK, Weintraub MN (2014) Crop rotation complexity regulates the decomposition of high and low-quality residues. Soil Biol Biochem 78:243-254

Montri A, Biernbaum JA (2009) Management of the soil environment in high tunnels. HortTech 19:34-36

Moreti D, Alves MC, Valério Filho WV, Carvalho MP (2007) Soil chemical attributes of a Red Latosol under different systems of preparation, management, and covering plants. Rev Bras Ci Solo 31(1):167-175

Nair A, Carpenter BH, Tillman JL, Jokela DL (2014) Integrating cover crops in high tunnel crop production. Iowa State Research Farm Progress Reports. 2009

Nascente AS, Stone LF (2018) Cover crops as affecting soil chemical and physical properties and development of upland rice and soybean cultivated in rotation. Rice Sci 25(6):340-349 
Neugschwandtner RW, Kaul HP (2014) Sowing ratio and N fertilization affect yield and yield components of oat and pea in intercrops. Field Crops Res 155:159-163

O'Connell S, Rivard C, Peet MM, Harlow C, Louws F (2012) High tunnel and field production of organic heirloom tomatoes: yield, fruit quality, disease and microclimate. Hort Sci 47:1283-1290

Ontl TA, Cambardella CA, Schulte LA, Kolka RK (2015) Factors influencing soil aggregation and particulate organic matter responses to bioenergy crop across a topographic gradient. Geoderma 255-256:1-11

Ostrowska A, Gawliński S, Szczubiałka Z (1991) Methods of analysis and evaluation of soil properties and plant - catalogue. Warsaw: Institute of Environmental Protection (In: Polish).

Peel MC, Finlayson BL, McMahon TA (2007) Updated world map of the Köppen-Geiger climate classification. Hydrol Earth Syst Sci 11:1633-1644

PN-A-75101-03 (1990) Fruit and vegetables. Sample preparation and methods of physicochemical tests - determination of dry matter content by gravimetric method. Polish Committee for Standardization.

PN-R-04032 (1998) Soil and mineral materials. Sampling and determination of particle size distribution. Polish Committee for Standardization.

PN-A-04019 (1998) Food products - determination of vitamin C content. Polish Committee for Standardization.

Poeplau C, Don A (2015) Carbon sequestration in agricultural soils via cultivation of cover crops - a meta-analysis. Agric Ecosyst Environ 200:33-41

Ranells NN, Wagger MG (1997) Grass-legume bicultures as winter annual cover crops. Agron J 89:659-665

Rosecrance RC, McCarty GW, Shelton DR, Teasdale JR (2000) Denitrification and $\mathrm{N}$ mineralization from hairy vetch (Vicia villosa Roth) and rye (Secale cereale L.) cover crop monocultures and bicultures. Plant Soil 227:283-290

Rudisill MA, Bordelon BP, Turco RF, Hoagland LA (2015) Sustaining soil quality in intensively managed high tunnel vegetable production systems: a role for green manures and chicken litter. Hort Sci 50:461-468

Ruffo ML, Bollero GA (2003) Modeling rye and hairy vetch residues decomposition as a function of degree-days and decomposition-days. Agron J 95:900-907

Sady W (2000) Field vegetable fertilization. Plantpress, Kraków [In Polish]

Sainju UM, Dris R, Singh B (2003) Mineral nutrition of tomato. J Food Agric Environ 1(2):176-183

Sainju UM, Whitehead WF, Singh BP (2005) Biculture legume-cereal cover crops for enhanced biomass yield and carbon and nitrogen. Agron J 97:1403-1412
Schipanski M, Barbercheck M, Douglas MR, Finney DM, Haider K, Kaye JP et al (2014) A conceptual framework for evaluating ecosystem services provided by cover crops in agroecosystems. Agric Syst 125:12-22

Siwek P, Libik A (2012) Plastic covers in Polish horticulture. Plasticulture 131:65-73

Spaccini R, Piccolo A (2013) Effects of field managements for soil organic matter stabilization on water-stable aggregate distribution and aggregate stability in three agricultural soils. J Geochem Explor 129:45-51

Sugihara Y, Ueno H, Hirata T, Araki H (2013) Uptake and distribution of nitrogen derived from hairy vetch used as cover crop by tomato plant. J Jpn Soc Horti Sci 82:30-38

Sugiyama A, Yazaki K (2012) Root exudates of legume plants and their involvement in interactions with soil microbes. In: Vivanco JM, Baluška F (ed) Secretions and exudates in biological systems, Signaling and communication in plants 12:27-48.

Świątkiewicz I, Kalisz A, Bucki P (2020) Microclimatic conditions and physico-chemical properties of soil in intensive ecological vegetable crops rotation in high tunnel Acta Scien Pol Hort Cult 19(3):73-87

Thorup-Kristensen K, Magid J, Jensen LS (2003) Catch crops and green manures as biological tools in nitrogen management in temperate zones. Adv Agron 79:227-302

Wang M, Zheng Q, Shen Q, Guo S (2013) The critical role of potassium in plant stress response. Int $\mathrm{J}$ Mol Sci 14(4):7370-7390

Weil R, Kremen A (2007) Thinking across and beyond disciplines to make cover crops pay. J Sci Food Agric 87:551-557

Wohlenberg EV, Reichert JM, Reinert DJ, Blume E (2004) Aggregation dynamics of a sandy soil under five cropping systems in rotation and in succession. Rev Bras Ci Solo 28(5):891-900

Zaniewicz-Bajkowska A, Franczuk J, Rosa R, Kosterna E (2012) Green manure in Mazowsze. Formator, Toruń, Poland. [In Polish].

Publisher's note Springer Nature remains neutral with regard to jurisdictional claims in published maps and institutional affiliations. 